\title{
Creep and Stress Relaxation Anisotropy of a Single-Crystal Superalloy
}

\author{
Mikael Segersäll, Johan Moverare, Daniel Leidermark and Kjell Simonsson
}

\section{Linköping University Post Print}

\section{Tweet}

N.B.: When citing this work, cite the original article.

Original Publication:

Mikael Segersäll, Johan Moverare, Daniel Leidermark and Kjell Simonsson, Creep and Stress Relaxation Anisotropy of a Single-Crystal Superalloy, 2014, Metallurgical and Materials Transactions. A, (45), 5, 2532-2544.

http://dx.doi.org/10.1007/s11661-014-2198-0

Copyright: ASM International

http://www.asminternational.org/

Postprint available at: Linköping University Electronic Press

http://urn.kb.se/resolve?urn=urn:nbn:se:liu:diva-105837 


\title{
Creep and Stress Relaxation Anisotropy of a Single-Crystal Superalloy
}

\author{
MIKAEL SEGERSÄLL, JOHAN J. MOVERARE, DANIEL LEIDERMARK, \\ and KJELL SIMONSSON
}

\begin{abstract}
In this study, the TMF stress relaxation and creep behavior at $1023 \mathrm{~K}$ and $1223 \mathrm{~K}\left(750{ }^{\circ} \mathrm{C}\right.$ and $950^{\circ} \mathrm{C}$ ) have been investigated for a Ni-based single-crystal superalloy. Specimens with three different crystal orientations along their axes were tested; $\langle 001\rangle,\langle 011\rangle$, and $\langle 111\rangle$, respectively. A highly anisotropic behavior during TMF stress relaxation was found where the $\langle 111\rangle$ direction significantly shows the worst properties of all directions. The TMF stress relaxation tests were performed in both tension and compression and the results indicate a clear tension/compression asymmetry for all directions where the greatest asymmetry was observed for the $\langle 001\rangle$ direction at $1023 \mathrm{~K}\left(750^{\circ} \mathrm{C}\right)$; here the creep rate was ten times higher in compression than tension. This study also shows that TMF cycling seems to influence the creep rate during stress relaxation temporarily, but after some time it decreases again and adapts to the pre-unloading creep rate. Creep rates from the TMF stress relaxation tests are also compared to conventional constant load creep rates and a good agreement is found.
\end{abstract}

DOI: $10.1007 / \mathrm{s} 11661-014-2198-0$

(C) The Minerals, Metals \& Materials Society and ASM International 2014

\section{INTRODUCTION}

Ni-BASED superalloys show remarkable mechanical and chemical properties at high temperatures. ${ }^{[1,2]}$ This makes them suitable as blade material for gas turbines and aero engines. Ni-based superalloys consist of the typical $\gamma / \gamma^{\prime}$-microstructure where the $\gamma^{\prime}$-phase works as strengthener in a matrix of $\gamma$. The $\gamma^{\prime}$-phase has an $\mathrm{L1}_{2^{-}}$ ordered structure and is rich of $\mathrm{Al}, \mathrm{Ta}$, and $\mathrm{Ti}$, while the $\gamma$-matrix typically contains higher amount of $\mathrm{W}$ and Mo. By using a material in single-crystal form instead of poly-crystal form both creep and fatigue properties are enhanced. ${ }^{[3]}$ Gas turbine blades in single-crystal form are most commonly casted with the $\langle 001\rangle$ crystallographic direction upwards. This direction has the lowest stiffness of all directions and therefore the best fatigue properties, which is of great importance for gas turbine blade components. Single-crystal superalloys exhibit an anisotropic behavior as well as a tension/compression asymmetry. ${ }^{[4-7]}$

In the literature, stress relaxation of single-crystal superalloys is often associated with shorter dwell times at high temperatures during thermomechanical fatigue (TMF) testing, for example dwell times of 5 minutes during each TMF cycle. ${ }^{[8,9]}$ However, sometimes longer dwell times are applied, for instance Ro et al. ${ }^{[10]}$ studied

MIKAEL SEGERSÄLL, Ph.D. Student, DANIEL LEIDERMARK, Associate Professor, and KJELL SIMONSSON, Professor, are with the Department of Management and Engineering, Linköping University, 58183 Linköping, Sweden. Contact e-mail: mikael.segersall@liu.se JOHAN J. MOVERARE, Associate Professor, is with the Department of Management and Engineering, Linköping University, and also with the Materials Technology, Siemens Industrial Turbomachinery AB, 61283 Finspång, Sweden.

Manuscript submitted April 25, 2013.

Article published online January 30, 2014 the effect of dwell times up to 10 hours during TMF and found that the fatigue life decreased with an increase in dwell time. Further, Zhang et al. ${ }^{[11]}$ applied a dwell time of 1 hour at $1173 \mathrm{~K}\left(900{ }^{\circ} \mathrm{C}\right)$ in compression at each cycle during TMF testing. In that study, three different stages of stress relaxation during the TMF tests were found and each stage was connected to a specific microstructural behavior. In another study ${ }^{[12]}$ dwell times of 30 to 60 minutes were applied during tensile loadings at temperatures from $973 \mathrm{~K}$ to $1273 \mathrm{~K}\left(700{ }^{\circ} \mathrm{C}\right.$ to $1000{ }^{\circ} \mathrm{C}$ ). Results showed that after the dwell time the stress had relaxed to an asymptotic stress value. During stress relaxation in Ni-based superalloys it seems like dislocation rearrangement and a decreased dislocation density are microstructural factors that influence the behavior. ${ }^{[13]}$

When superalloys are subjected to mechanical loads at high temperatures $\sim 1273 \mathrm{~K}\left(1000{ }^{\circ} \mathrm{C}\right)$ rafting of the microstructure is observed. Rafting is a directional coarsening of the $\gamma^{\prime}$-particles and is a diffusion-controlled process. ${ }^{[14]}$ Several studies have shown that rafting plays a vital role during high temperature creep. ${ }^{[15,16]}$ The orientation of the rafting is dependent on whether the alloy has a positive or negative lattice misfit between the $\gamma$-and $\gamma^{\prime}$-microconstituents. ${ }^{[17]}$ For alloys with a negative misfit (like MD2 used for this study) compressive loading leads to rafts parallel to the loading direction, $P$-type. Further, when alloys with a negative misfit are loaded in tension, rafts transverse to the loading direction will be obtained, $N$-type. Rafting does not always have to be harmful for the material. For example, research has shown how pre-rafting of $P$-type can improve creep properties at high temperature and low stress. ${ }^{[18]}$ Also isothermal high temperature fatigue lives have proven to be enhanced by a pre-rafted microstructure of $P$-type instead of having the virgin 
microstructure with $\gamma^{\prime}$-cuboids in a $\gamma$-matrix. ${ }^{[19,20]}$ In the same study pre-rafting of $N$-type seems to be detrimental to high temperature fatigue properties compared to the virgin microstructure with cuboidal $\gamma^{\prime}$-precipitates. ${ }^{[20]}$ Another study has also shown how $N$-type of rafts are deleterious to non-isothermal creep properties while rafting of $P$-type seems to decrease creep rates and therefore enhance the non-isothermal creep properties. ${ }^{[21]}$

The creep performance is strongly influenced by the crystal orientation of the single-crystal superalloy. Literature often concludes that the $\langle 011\rangle$ direction has worse creep properties compared to the $\langle 001\rangle$ and $\langle 111\rangle$ directions. ${ }^{[22-25]}$ One explanation for this is the orientation of the rafted $\gamma^{\prime}$-particles. ${ }^{[22]}$ In $\langle 011\rangle$ oriented specimens, the orientation of the rafting is $45 \mathrm{deg}$ from the stress axis while for $\langle 001\rangle$ specimens the rafting is either parallel or perpendicular to the stress axis. The $\gamma^{\prime}$-rafts oriented $45 \mathrm{deg}$ from the stress axis do not act as good obstacles for dislocation motion as the parallel or perpendicular $\gamma^{\prime}$-rafts, this is therefore one reason why the $\langle 011\rangle$ direction show less creep strength than the $\langle 001\rangle$ direction. Other researchers ${ }^{[23]}$ state that the tensile creep properties decrease in the sequence $\langle 111\rangle$, $\langle 001\rangle,\langle 011\rangle$ while in compression the creep properties decreases in the sequence $\langle 001\rangle,\langle 111\rangle,\langle 011\rangle$. Kakehi $^{[24,25]}$ showed that the $\langle 001\rangle$ direction has better creep properties compared to the $\langle 011\rangle$ direction. In the same study, it was found that $\langle 001\rangle$ shows better properties in tension than compression during creep at $973 \mathrm{~K}\left(700{ }^{\circ} \mathrm{C}\right)$ while $\langle 011\rangle$ was stronger in compression than in tension. Thus, an inverted tension/compression asymmetry was found for the $\langle 001\rangle$ and $\langle 011\rangle$ directions. The tension/compression asymmetry in creep strength for the $\langle 001\rangle$ direction was also studied by Tsuno et al. ${ }^{[4]}$ where they found that the asymmetry was attributed to twin formation during compression creep. Mechanical twins weaken the material and therefore the $\langle 001\rangle$ direction has better creep strength in tension compared to compression. They also concluded that the creep asymmetry increases with increased temperature from $1023 \mathrm{~K}$ to $1173 \mathrm{~K}\left(750{ }^{\circ} \mathrm{C}\right.$ to $\left.900{ }^{\circ} \mathrm{C}\right)$.

Hence, good TMF and creep properties are of great importance for materials considered for gas turbine blades. The purpose of this paper is to study the stress relaxation behavior during component like TMF cycling for a single-crystal superalloy in different crystal orientations and at different temperatures. For modeling issues it is also of importance to investigate the tension/ compression asymmetry during stress relaxation as well as how TMF cycling seems to influence the stress relaxation. It is mainly the creep rates that are of importance when performing modeling and therefore creep rates from the TMF stress relaxation tests are compared to creep rates from the more conventional constant load creep tests.

\section{EXPERIMENTAL PROCEDURE}

In this study, the Ni-based single-crystal superalloy MD2 with chemical composition Ni-5.1Co-6.0Ta-8.0Cr-
Table I. Deviation from the Ideal Orientation for all Specimens Tested in the TMF Stress Relaxation Tests

\begin{tabular}{lcc}
\hline & \multicolumn{2}{c}{$\begin{array}{c}\text { Deviation from the Ideal } \\
\text { Orientation [deg] }\end{array}$} \\
\cline { 2 - 3 } & $\begin{array}{c}1023 \mathrm{~K} \\
\left(750^{\circ} \mathrm{C}\right)\end{array}$ & $\begin{array}{c}1223 \mathrm{~K} \\
\left(950^{\circ} \mathrm{C}\right)\end{array}$ \\
\hline$\langle 001\rangle$ IP & 1.8 & 3.7 \\
$\langle 001\rangle$ OP & 6.2 & 5.9 \\
$\langle 011\rangle$ IP & 1.7 & 3.6 \\
$\langle 011\rangle$ OP & 1.9 & 6.7 \\
$\langle 111\rangle$ IP & 5.5 & not tested \\
$\langle 111\rangle$ OP & 2.5 & not tested \\
\hline
\end{tabular}

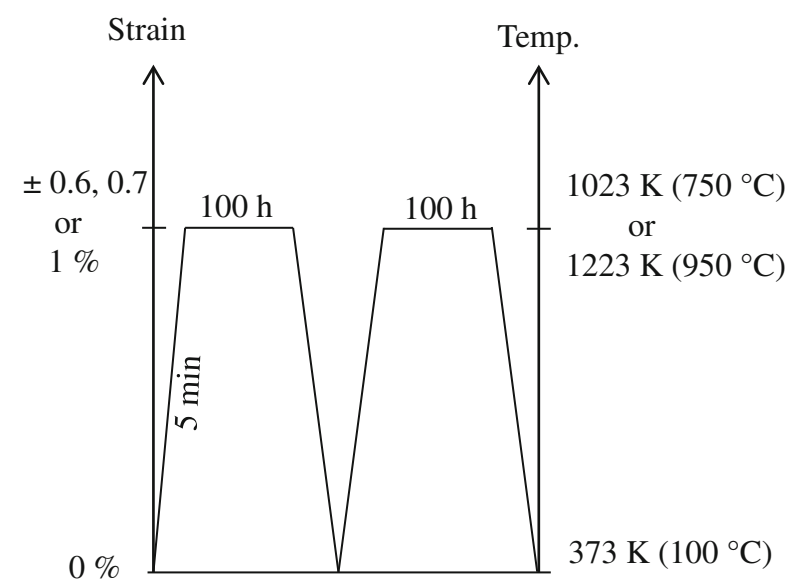

Fig. 1-The TMF cycle used in the stress relaxation tests.

8.1W-5.0Al-1.3Ti-2.1Mo-0.1Hf-0.1Si in wt pet is considered. The material was solution heat treated at $1563 \mathrm{~K}\left(1290{ }^{\circ} \mathrm{C}\right)$ for 8 hours followed by a two-stage aging process with 3 hours at $1373 \mathrm{~K}\left(1100{ }^{\circ} \mathrm{C}\right)$ and 24 hours at $1123 \mathrm{~K}\left(850^{\circ} \mathrm{C}\right)$. Test specimens were machined from cast bars and the deviation from the ideal orientation was determined to less than 7 deg for all specimens, see Table I.

The stress relaxation tests were performed as TMF tests in an Instron servo-hydraulic TMF machine and the machine was carefully aligned to prevent buckling of the specimens. Smooth specimens with a diameter of $6 \mathrm{~mm}$ and a parallel length of $24 \mathrm{~mm}$ were used. The tests were conducted as strain controlled TMF cycles with a temperature range from $373 \mathrm{~K}\left(100{ }^{\circ} \mathrm{C}\right)$ to either $1023 \mathrm{~K}\left(750{ }^{\circ} \mathrm{C}\right)$ or $1223 \mathrm{~K}\left(950^{\circ} \mathrm{C}\right)$ where a dwell time of 100 hours was applied at maximum temperature $\left(T_{\max }\right)$, see Figure 1 for an illustration of the TMF cycle used in the stress relaxation tests. The strain was measured with an axial high temperature extensometer with a gauge length of $12.5 \mathrm{~mm}$. In order to have control over the mechanical strain, the thermal strain was subtracted from the measured total strain. After the 100 hours dwell time, the temperature was lowered to $373 \mathrm{~K}\left(100{ }^{\circ} \mathrm{C}\right)$ and zero mechanical strain before the second cycle was initiated. Each specimen was subjected to two cycles, i.e., no specimens were cycled to failure. Consequently, a total dwell time of 200 hours at $T_{\max }$ 
was applied for each specimen. For a $T_{\max }$ of $1023 \mathrm{~K}$ $\left(750{ }^{\circ} \mathrm{C}\right)$, the $\langle 001\rangle,\langle 011\rangle$, and $\langle 111\rangle$ directions were tested. However, for a $T_{\max }$ of $1223 \mathrm{~K}\left(950{ }^{\circ} \mathrm{C}\right)$ only the $\langle 001\rangle$ and $\langle 011\rangle$ directions were tested. To obtain approximately the same inelastic strain for all directions (approximately $0.5 \mathrm{pct}$ ), different total mechanical strain ranges $\left(\Delta \varepsilon_{\text {mech }}\right)$ were used for the different directions at both $1023 \mathrm{~K}$ and $1223 \mathrm{~K}\left(750{ }^{\circ} \mathrm{C}\right.$ and $\left.950{ }^{\circ} \mathrm{C}\right)$. The $\langle 001\rangle$ specimens were subjected to a $\Delta \varepsilon_{\text {mech }}$ of 1 pct, the $\langle 011\rangle$ specimens to 0.7 pct while the $\langle 111\rangle$ specimens were subjected to a $\Delta \varepsilon_{\text {mech }}$ of 0.6 pct. For each direction and $T_{\max }$, one specimen was subjected to an In-Phase TMF cycle (IP TMF) while one other specimen was subjected to an Out-of-Phase TMF cycle (OP TMF). An IP TMF cycle implies tensile stress relaxation at $T_{\max }$ while OP TMF implies compressive stress relaxation at $T_{\max }$.

Constant load creep tests were carried out using creep specimens, conforming to the European standard EN10291:2000. The specimens had a $5 \mathrm{~mm}$ diameter and $24.5 \mathrm{~mm}$ gauge length. The creep temperature was controlled to within $\pm 2 \mathrm{~K}\left(2^{\circ} \mathrm{C}\right)$ of the target creep temperature. The actual creep strain was determined by continuous measurement of the increase in sample length. Again, the $\langle 001\rangle,\langle 011\rangle$, and $\langle 111\rangle$ crystal orientations were tested at $1023 \mathrm{~K}\left(750{ }^{\circ} \mathrm{C}\right)$ but at $1223 \mathrm{~K}\left(950{ }^{\circ} \mathrm{C}\right)$ only the $\langle 001\rangle$ and $\langle 011\rangle$ directions were tested.

After the tests, all specimens were examined by stereo microscopy before they were cut parallel to the loading direction for further microstructural investigation by scanning electron microscopy (SEM). The SEM samples were prepared by grinding and mechanical polishing, but no samples were etched. The microstructure investigation was performed in a Hitachi SU70 SEM with an annular backscatter detector making it possible to produce images by electron channeling contrast imaging (ECCI).

\section{RESULTS}

\section{A. TMF Stress Relaxation Tests}

Concerning the TMF stress relaxation tests with a $T_{\max }$ of $1023 \mathrm{~K}\left(750^{\circ} \mathrm{C}\right)$ a difference between the directions is noticed already when loading into the TMF cycle. The $\langle 011\rangle$ specimens showed a serrated yielding behavior during the loading, both in tension and compression. On the other hand, the yielding of both the $\langle 001\rangle$ and $\langle 111\rangle$ directions were more stable. From the $\langle 011\rangle$ specimens also a clear noise was heard during the loading phase, which was not the case for either the $\langle 001\rangle$ or $\langle 111\rangle$ direction. For the specimens subjected to a $T_{\max }$ of $1223 \mathrm{~K}\left(950^{\circ} \mathrm{C}\right)$ no serrated yielding was observed and no noise was heard.

Figure 2 shows how the stress is relaxing during the 200 hours dwell time for all specimens during the two TMF cycles. Note that unloading and reloading after the first TMF cycle occur after 100 hours in all tests. Since all orientations are loaded to different mechanical strain ranges with the target to have approximately 0.5 pct inelastic strain when entering the dwell time, all stress relaxation curves in Figure 2 have a different initial stress. The differences in initial stress reflect the differences in flow stress for the different orientations at the different temperatures. However, since the initial stress is rather high, stress relaxation will initially occur very rapidly meaning that any differences in the initial stress will have no significant influence on the stress level after 1 hour of the dwell time which is of interest in this study.

As expected, testing at $1223 \mathrm{~K}\left(950^{\circ} \mathrm{C}\right)$ results in lower stress states compared to tests at $1023 \mathrm{~K}\left(750{ }^{\circ} \mathrm{C}\right)$. Moreover, a clear anisotropic behavior is observed during the TMF stress relaxation. At $1023 \mathrm{~K}\left(750{ }^{\circ} \mathrm{C}\right)$, the $\langle 111\rangle$ specimens relax to a significantly lower stress state compared to both the $\langle 001\rangle$ and $\langle 011\rangle$ directions. After the first 100 hours cycle, the stress is only

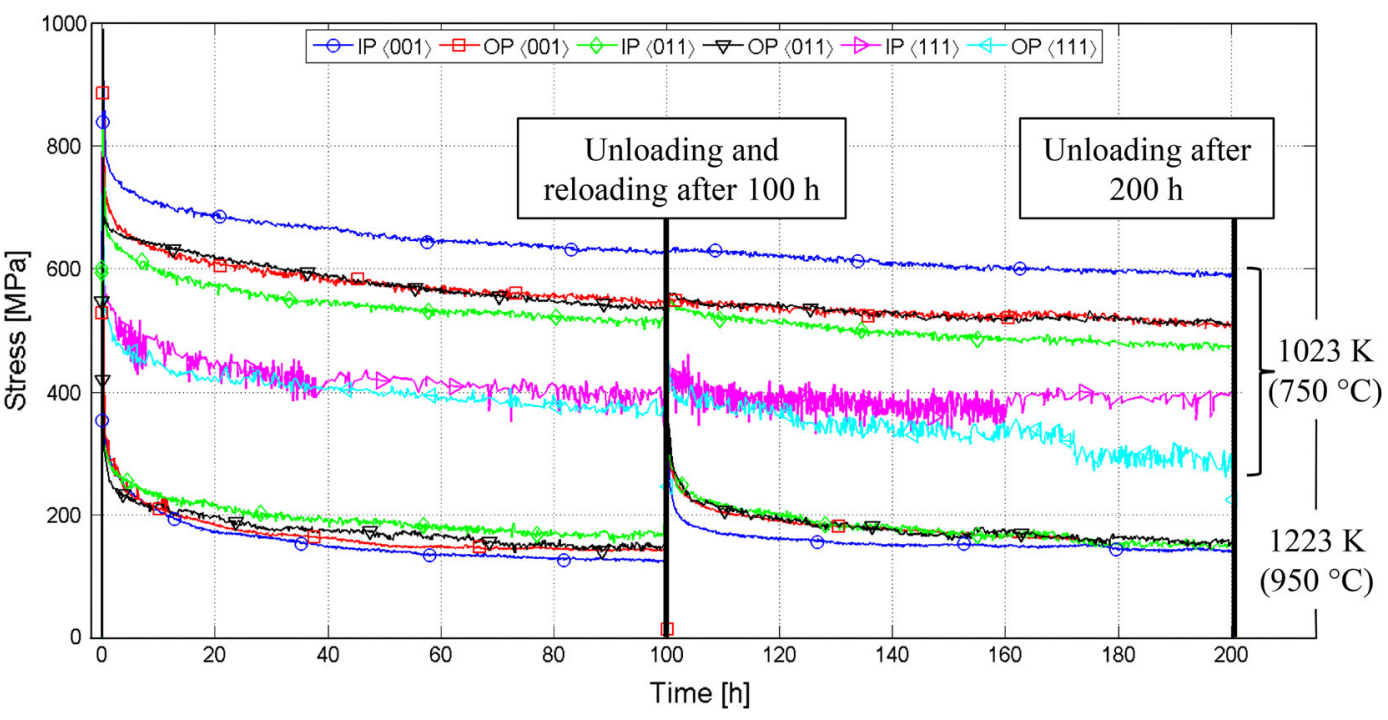

Fig. 2 (Color online) Stress relaxation over $200 \mathrm{~h}$ for the $\langle 001\rangle,\langle 011\rangle$, and $\langle 111\rangle$ directions in both tension (IP) and compression (OP). The plot shows absolute stress $v s$ time. 
approximately $360 \mathrm{MPa}$ for the $\langle 111\rangle$ direction while both $\langle 001\rangle$ and $\langle 011\rangle$ directions are well above $500 \mathrm{MPa}$. It should be noted that the stress relaxation in the $\langle 111\rangle$ direction is very unstable compared to the other directions. This instability should be attributed to TMF machine instabilities rather than any microstructural differences between the three directions. One reason can be that the high stiffness in the $\langle 111\rangle$ direction makes it more difficult for the TMF machine to take care of the instability. At this temperature the $\langle 001\rangle$ direction shows better properties than the $\langle 011\rangle$ direction. However at $1223 \mathrm{~K}\left(950{ }^{\circ} \mathrm{C}\right)$, the $\langle 011\rangle$ direction relaxes to a higher stress state compared to the $\langle 001\rangle$ direction. The $\langle 111\rangle$ direction was not tested at this temperature, as mentioned previously.

A tension/compression asymmetry is observed for all crystal orientations during the TMF stress relaxation tests. The asymmetry is most pronounced at $1023 \mathrm{~K}\left(750^{\circ} \mathrm{C}\right)$ for the $\langle 001\rangle$ direction, where tensile loading leads to a significantly higher stress state compared to compressive loading. Here the difference in stress is $\sim 80 \mathrm{MPa}$ after 200 hours. An opposite tension/compression asymmetry is observed for the $\langle 011\rangle$ specimens at this temperature; here tensile loading leads to a lower stress state compared to compressive loading. Another difference is that the unloading after 100 hours leads to an increase in stress state for the $\langle 011\rangle$ direction when the material is loaded into the second 100 hours cycle. But, after some time the material relaxes and adapts into the pre-unloading behavior. For the $\langle 001\rangle$ direction the unloading after 100 hours does not have an influence on the stress state.

At $1223 \mathrm{~K}\left(950^{\circ} \mathrm{C}\right)$, a different tension/compression asymmetry is observed compared to $1023 \mathrm{~K}\left(750{ }^{\circ} \mathrm{C}\right)$. The $\langle 001\rangle$ direction is stronger in compression than tension, while the $\langle 011\rangle$ direction is stronger in tension than compression. At this temperature, the unloading after 100 hours leads to a significantly higher stress state at reloading. This is the case for both $\langle 001\rangle$ and $\langle 011\rangle$ directions at $1223 \mathrm{~K}\left(950^{\circ} \mathrm{C}\right)$, but only for the $\langle 011\rangle$ direction at $1023 \mathrm{~K}\left(750^{\circ} \mathrm{C}\right)$.

Finally, it is to be noted that none of the TMF stress relaxation tests led to failure.

\section{B. Microscopy}

For the TMF stress relaxation tests, where the specimens were subjected to dwell times at $1023 \mathrm{~K}$ $\left(750{ }^{\circ} \mathrm{C}\right.$ ), distinct crystallographic deformation bands across the specimens are found for the $\langle 011\rangle$ direction, both in tension and compression, see Figure 3(a). Such distinct deformation bands are not visible for any of the $\langle 001\rangle$ or $\langle 111\rangle$ specimens at this temperature. However, when dwell times were applied at $1223 \mathrm{~K}\left(950{ }^{\circ} \mathrm{C}\right)$ instead, all crystal orientations show crystallographic deformation bands on the surfaces. At this temperature, the deformation bands are even more distinct compared to the deformation bands found at the $\langle 011\rangle$ oriented specimens at $1023 \mathrm{~K}\left(750^{\circ} \mathrm{C}\right)$. All slip traces are consistent with slip on one of the $\{111\}$ planes. Figure $3(\mathrm{~b})$ shows deformation bands on the $\langle 011\rangle$ specimens subjected to tensile stresses at $1223 \mathrm{~K}\left(950^{\circ} \mathrm{C}\right)$. On this specimen, slip traces on several $\{111\}$ planes are found.
Figure 3(c) shows deformation bands on the $\langle 001\rangle$ specimens subjected to compression at $1223 \mathrm{~K}$ $\left(950{ }^{\circ} \mathrm{C}\right)$. Concerning the $\langle 001\rangle$ direction subjected to tensile stresses, in addition to the crystallographic deformation bands, also wavy deformation bands are found, see Figure 3(d). This indicates that several slip systems are active during deformation in this direction.

When investigating the deformation bands inside the specimens by SEM, the bands are often clearly visible at low magnification, as seen in Figure 4(a). However, at higher magnification the crystallographic deformation bands are often difficult to detect, Figure 4(b), and it seems that the deformation bands are not twinning or massive shearing of the $\gamma / \gamma^{\prime}$-microstructure. Precipitation of topologically close-packed (TCP) phases are sometimes visible in the microstructure, see Figures 4(a) through (d). Since the precipitation of TCP phases often is parallel to the deformation bands it seems like the TCP phases have precipitated along the crystallographic deformation bands. Occasionally, more distinct deformation bands are visible within the microstructure; see Figure 5 for one of those bands in the $\langle 011\rangle$ specimen subjected to $1223 \mathrm{~K}\left(950{ }^{\circ} \mathrm{C}\right)$ in compression. As previously, it seems that none of these distinct bands are twinning or shearing of the $\gamma / \gamma^{\prime}$-microstructure. They are more likely bundles of glide bands. Further SEM investigation shows very little deformation in the $\gamma / \gamma^{\prime}$ microstructure and this is not either expected since no specimens were tested until failure.

However, Figure 6 reveals a type of crystallographic deformation in the $\gamma / \gamma^{\prime}$-microstructure for the $\langle 001\rangle$ specimen subjected to TMF stress relaxation in compression at $1023 \mathrm{~K}\left(750{ }^{\circ} \mathrm{C}\right)$. This deformation is believed to be nano-twinning, but to confirm this, for example transmission electron microscopy (TEM) has to be used which was not available in this study. However, a problem with TEM in this case would be the difficulty to find the exact position of the twins. In addition, when polishing of the thin TEM samples there is a risk to lose the twins. Another option to prove the twinning phenomena is to perform orientation imaging microscopy (OIM) by use of electron backscatter diffraction (EBSD). However, with the available EBSD equipment in this study, the twins were not detectable due to their nano size.

Rafting of the $\gamma / \gamma^{\prime}$-microstructure is visible for specimens subjected to dwell times at $1223 \mathrm{~K}\left(950{ }^{\circ} \mathrm{C}\right)$. The MD2 alloy has a negative misfit between the $\gamma^{\prime}$ - and $\gamma$-microconstituents and this implies that tensile loaded specimens show rafts transverse to the loading direction ( $N$-type) while material loaded in compression show rafts parallel to the loading direction ( $P$-type). Figure 7 displays $N$-type of rafting; the $\gamma^{\prime}$-particles, which are cuboidal in virgin condition, are coarsened and oriented transverse to the load direction.

The deformation behaviors and microstructural features from the TMF stress relaxation tests are summarized in Table II.

\section{Constant Load Creep Tests}

At $1023 \mathrm{~K}\left(750^{\circ} \mathrm{C}\right)$, constant load creep tests were performed in all three crystal orientations $\langle 001\rangle,\langle 011\rangle$, 

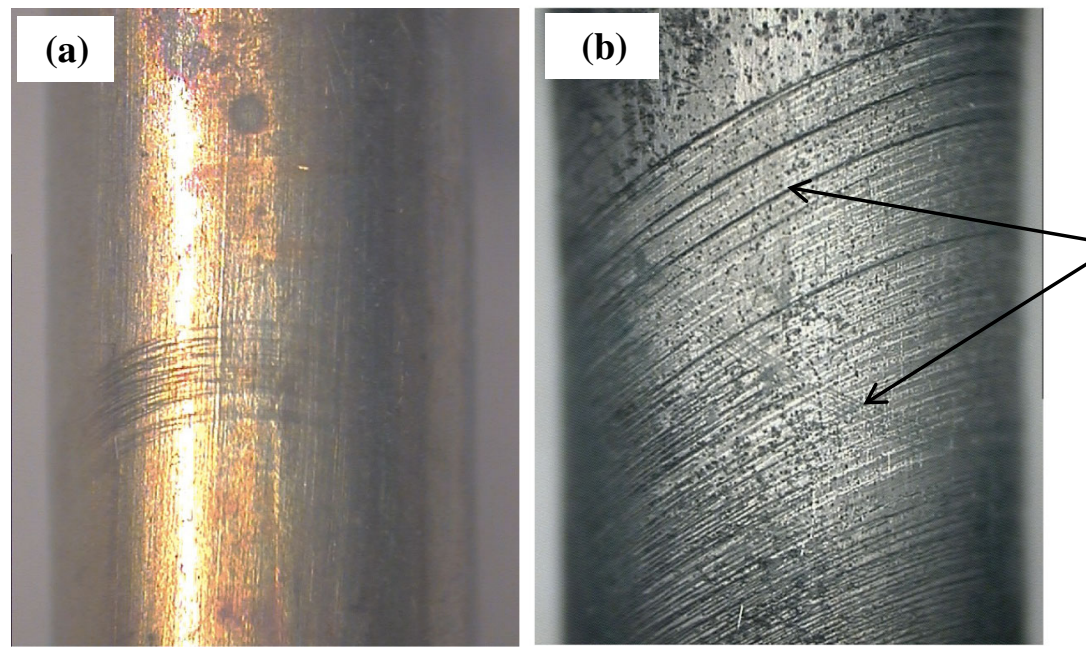

Slip traces on

several $\{111\}$

planes
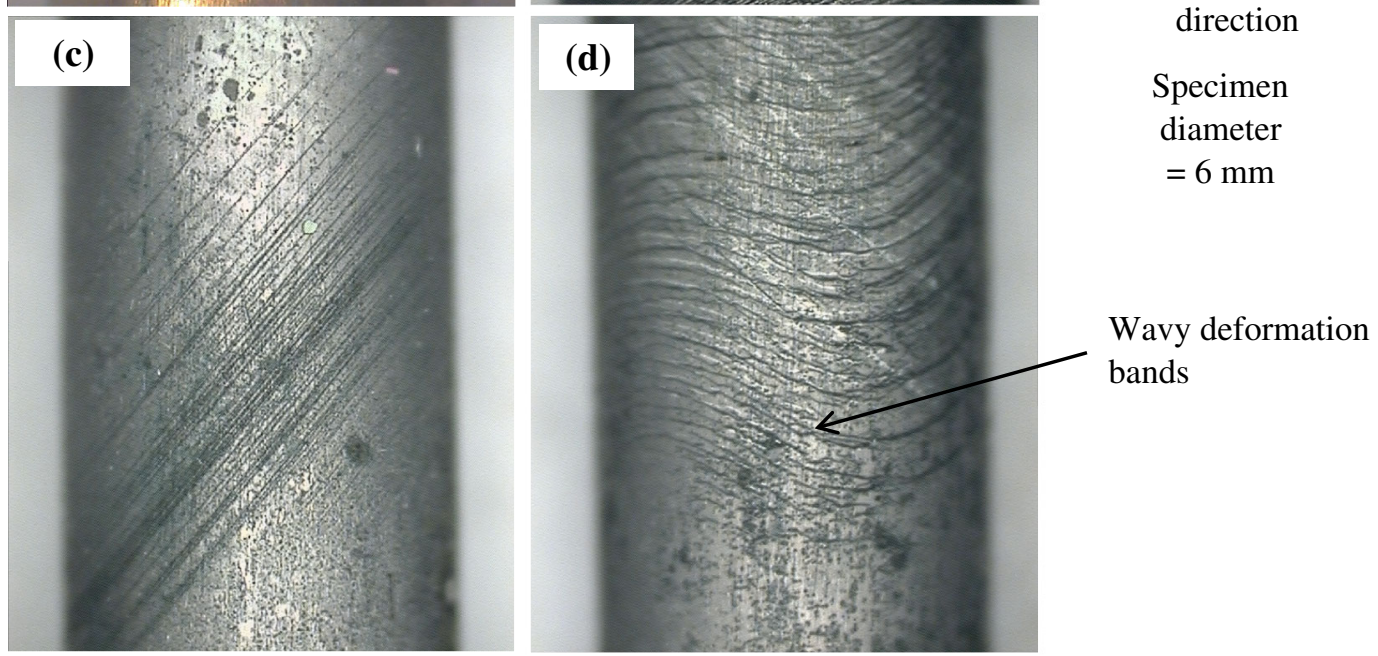

Fig. 3-Deformation bands on specimens subjected to TMF stress relaxation tests: $(a)$ the $\langle 011\rangle$ specimen subjected to $1023 \mathrm{~K}\left(750{ }^{\circ} \mathrm{C}\right)$ in compression (OP), $(b)$ the $\langle 011\rangle$ specimen subjected to $1223 \mathrm{~K}\left(950^{\circ} \mathrm{C}\right)$ in tension (IP), $(c)$ the $\langle 001\rangle$ specimen subjected to $1223 \mathrm{~K}\left(950{ }^{\circ} \mathrm{C}\right)$ in compression (OP) and $(d)$ the $\langle 001\rangle$ specimen subjected to $1223 \mathrm{~K}\left(950^{\circ} \mathrm{C}\right)$ in tension (IP).

and $\langle 111\rangle$ and at different loads. However, at $1223 \mathrm{~K}$ $\left(950{ }^{\circ} \mathrm{C}\right)$ only the $\langle 001\rangle$ and $\langle 011\rangle$ directions were tested, and different loads were applied also at this temperature. The results from the creep test are summarized in Figure 8, where a Larson-Miller plot of all the creep data is provided. From that plot it can be observed that the $\langle 001\rangle$ direction generally shows the best creep properties of all directions tested.

The $\langle 011\rangle$ direction generally shows very low creep ductility compared to both other directions, see for example Figure 9 for creep results at $600 \mathrm{MPa}$ and $1023 \mathrm{~K}\left(750^{\circ} \mathrm{C}\right)$. This direction also shows crystallographic fractures while the fracture behavior for the $\langle 001\rangle$ and $\langle 111\rangle$ directions instead are more random. From the backscattered electron image of the $\langle 011\rangle$ direction displayed in Figure 9(b), it is obvious that the crystallographic fracture has occurred along one of the $\{111\}$ planes. Sometimes cube slip may occur; however in this case it seems that octahedral slip is dominating. When analyzing the creep tests at $1223 \mathrm{~K}\left(950^{\circ} \mathrm{C}\right)$ the same behavior is observed; the $\langle 011\rangle$ direction shows a low creep ductility and crystallographic fractures while the $\langle 001\rangle$ direction shows better creep ductility and more random fractures.

Further, from Figure 9(a) is it visible that the $\langle 001\rangle$ direction shows the highest creep rupture life of all directions, 6853 hours compared to 732 hours for the $\langle 011\rangle$ direction and 1594 hours for the $\langle 111\rangle$ direction. As can be seen in Figure 9(a), the $\langle 011\rangle$ direction initially has a creep rate similar to the $\langle 001\rangle$ direction but the creep rupture life is low due to the very poor creep ductility shown by the $\langle 011\rangle$ direction. That the $\langle 011\rangle$ direction has a poor creep ductility which is visible for all stress levels tested at this temperature. At $1223 \mathrm{~K}$ $\left(950{ }^{\circ} \mathrm{C}\right)$, the $\langle 011\rangle$ direction still shows very low creep ductility compared to $\langle 001\rangle$, which is shown in Figure 10. However, it is interesting to compare the creep rupture lives for both directions at this temperature. At $200 \mathrm{MPa}$ and $1223 \mathrm{~K}\left(950{ }^{\circ} \mathrm{C}\right)$ the creep rupture lives are rather similar for both directions. But at lower stresses, around $120 \mathrm{MPa}$ and $1223 \mathrm{~K}\left(950{ }^{\circ} \mathrm{C}\right)$, the creep rupture lives for the two directions diverge significantly. Here the creep rupture life for the $\langle 001\rangle$ direction is in the order of three times greater than the 

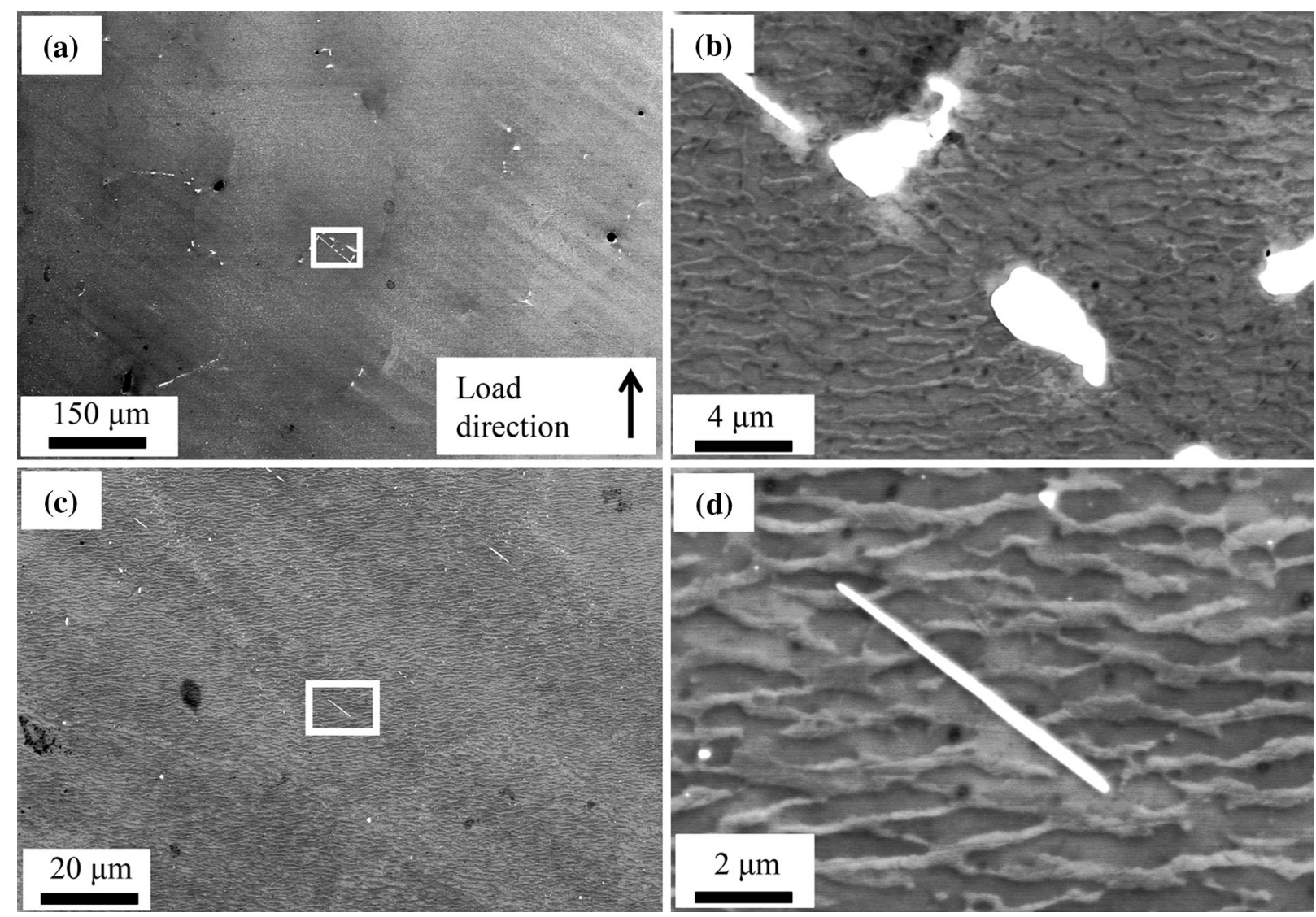

Fig. 4 - Backscattered electron images of $\langle 011\rangle$ specimens subjected to TMF stress relaxation tests at $1223 \mathrm{~K}\left(950{ }^{\circ} \mathrm{C}\right)$ in tension (IP): $(a)$ crystallographic deformation band at low magnification, $(b)$ magnification of $(\mathrm{a}),(c)$ precipitation of TCP phases within the deformation bands, $(d)$ magnification of (c).

rupture life for the $\langle 011\rangle$ direction; 15,875 and 4456 hours, respectively. This is mainly due to decreasing creep ductility with decreasing stress and increasing exposure time for the $\langle 011\rangle$ direction.

The poor creep ductility and crystallographic fracture for the $\langle 011\rangle$ direction during constant load creep tests can be compared to the TMF stress relaxation tests at $1023 \mathrm{~K}\left(750^{\circ} \mathrm{C}\right)$ where crystallographic deformation bands were found for the $\langle 011\rangle$ direction. Thus, it seems like deformation for $\langle 011\rangle$ oriented materials is more localized to a number of deformation bands at this temperature compared to the $\langle 001\rangle$ and $\langle 111\rangle$ directions. This may explain the crystallographic fractures exhibited by the $\langle 011\rangle$ direction in the constant load creep tests.

\section{Evaluation of Creep Rates}

To be able to investigate and compare creep rates from both the TMF stress relaxation tests and the conventional constant load creep tests; creep rates from both types of tests must be evaluated. In order to obtain creep rates from stress relaxation tests, a method that first was presented by Hart ${ }^{[26]}$ and later also used by Woodford $^{[27]}$ have been used. During the TMF stress relaxation testing, the total strain is kept constant during the dwell time:

$$
\varepsilon_{\mathrm{tot}}=\varepsilon_{\text {elastic }}+\varepsilon_{\text {creep }}=\text { constant. }
$$

Thus, the following differentiated equation must hold during the stress relaxation:

$$
\dot{\varepsilon}_{\text {tot }}=\dot{\varepsilon}_{\text {elastic }}+\dot{\varepsilon}_{\text {creep }}=0 .
$$

Assuming that the uniaxial elastic strain is $\varepsilon_{\text {elastic }}=\sigma / E$, the following relationship can be derived from Eq. [2]:

$$
\dot{\varepsilon}_{\text {creep }}=-\frac{1}{E} \dot{\sigma}
$$

Thus, it is possible to evaluate the creep strain rate $\dot{\varepsilon}_{\text {creep }}$ from the TMF stress relaxation rate $\dot{\sigma}$ if the Young's modulus $E$ is known. Therefore, the singlecrystal elastic constants were determined by resonance measurements at the different temperatures and are listed in Table III.

Furthermore, the TMF stress relaxation rate $\dot{\sigma}$ was determined as the slope of the stress $v s$ time curve at a number of positions (10 to 20) along the stress relaxation curve for each test. The positions along the curve were taken in intervals of approximately $10 \mathrm{MPa}$ in stress change. Creep rates for the constant load creep tests were evaluated as the average rate to 0.5 pct creep 

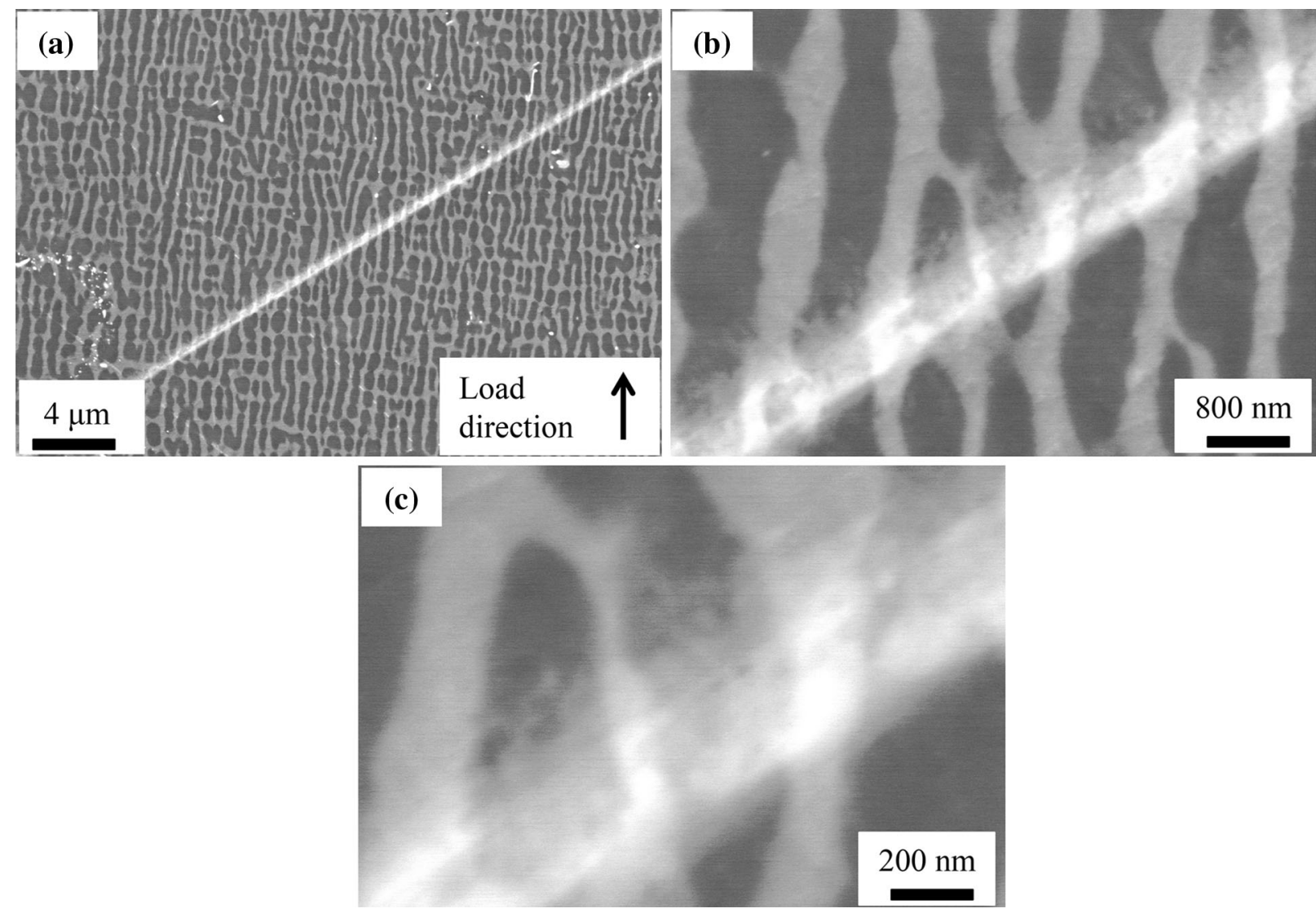

Fig. 5-Backscattered electron images of the $\langle 011\rangle$ specimen subjected to TMF stress relaxation tests at $1223 \mathrm{~K}\left(950{ }^{\circ} \mathrm{C}\right)$ in compression $(\mathrm{OP})$ : $(a)$ deformation band, $(b)$ and $(c)$ magnifications of (a).

strain as well as the minimum creep rate during stage II creep.

Figures 11(a) through (c) display the evaluated creep rates from both the TMF stress relaxation tests as well as the constant load creep tests for the $\langle 001\rangle,\langle 011\rangle$, and $\langle 111\rangle$ directions, respectively. As expected creep rates are higher at $1223 \mathrm{~K}\left(950{ }^{\circ} \mathrm{C}\right)$ compared to $1023 \mathrm{~K}\left(750{ }^{\circ} \mathrm{C}\right)$. A significant tension/compression asymmetry in creep rate during TMF stress relaxation is detected for the $\langle 001\rangle$ direction at $1023 \mathrm{~K}\left(750{ }^{\circ} \mathrm{C}\right)$, see Figure 11(a). In this case, the creep rate in compression is ten times greater compared to the tensile creep rate. Regarding the $\langle 011\rangle$ and $\langle 111\rangle$ directions at this temperature no significant tension/compression asymmetry in creep rate during TMF stress relaxation can be observed, see Figures 11 (b) and (c). At $1223 \mathrm{~K}\left(950{ }^{\circ} \mathrm{C}\right)$ both the $\langle 001\rangle$ and $\langle 011\rangle$ directions show a small tension/compression asymmetry in creep rate.

To study how the creep rates are affected by TMF cycling; the creep rates from only the TMF stress relaxation tests have been plotted. Figures 12(a) through (d) provide comparisons between the first and second cycle creep rates during the TMF stress relaxation, in both tension and compression and for both temperatures. Generally the creep rates are higher in the second TMF cycle compared to the first cycle. In Figures 12(a) and (b) it is once again visible that the creep rate at $1023 \mathrm{~K}\left(750{ }^{\circ} \mathrm{C}\right)$ for the $\langle 111\rangle$ direction is rather high compared to both the $\langle 001\rangle$ and $\langle 011\rangle$ directions. At $1223 \mathrm{~K}\left(950{ }^{\circ} \mathrm{C}\right)$ the differences are smaller.

\section{DISCUSSION}

\section{A. Anisotropy}

From the TMF stress relaxation tests (Figures 2, 12) it is clearly visible that the material shows different properties in different directions, hence a clear anisotropy. The most significant anisotropy is that the $\langle 111\rangle$ direction seems to have the worst properties at $1023 \mathrm{~K}$ $\left(750{ }^{\circ} \mathrm{C}\right)$ since this direction relaxes to a significant lower stress state compared to both the $\langle 001\rangle$ and $\langle 011\rangle$ direction during the TMF stress relaxation tests. The $\langle 001\rangle$ direction shows slightly better properties than the $\langle 011\rangle$ direction at $1023 \mathrm{~K}\left(750{ }^{\circ} \mathrm{C}\right)$ which is in line with previous research claiming that $\langle 011\rangle$ oriented materials show worse creep properties compared to the $\langle 001\rangle$ direction. ${ }^{[24,25]}$ At $1223 \mathrm{~K}\left(950^{\circ} \mathrm{C}\right)$ the anisotropy is smaller. However, the $\langle 011\rangle$ direction shows slightly better properties compared to the $\langle 001\rangle$ direction.

The $\langle 011\rangle$ direction shows a serrated yielding behavior when loading into the TMF cycle in the stress relaxation tests with $T_{\max }$ of $1023 \mathrm{~K}\left(750{ }^{\circ} \mathrm{C}\right)$. For all other directions the yielding is more stable. This 

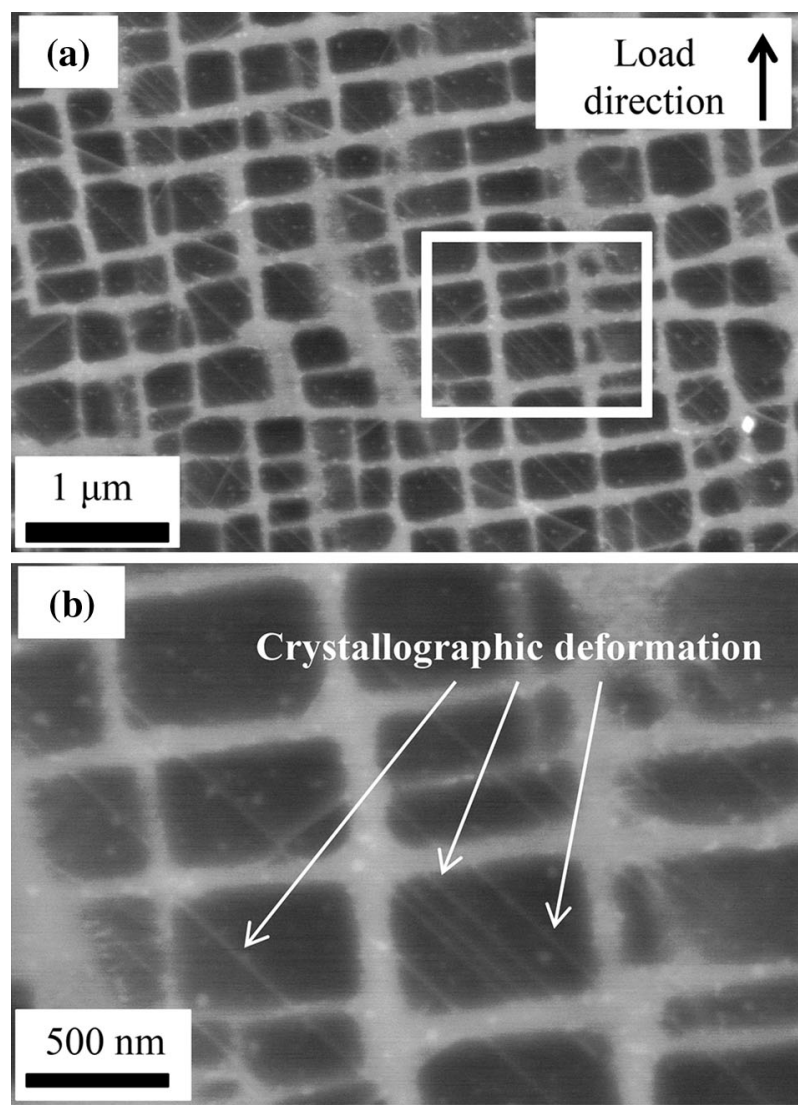

Fig. 6-Backscattered electron images of the $\langle 001\rangle$ specimen subjected to TMF stress relaxation tests at $1023 \mathrm{~K}\left(750^{\circ} \mathrm{C}\right)$ in compression (OP): (a) crystallographic deformation which is believed to be nano-twinning, (b) magnification of (a).

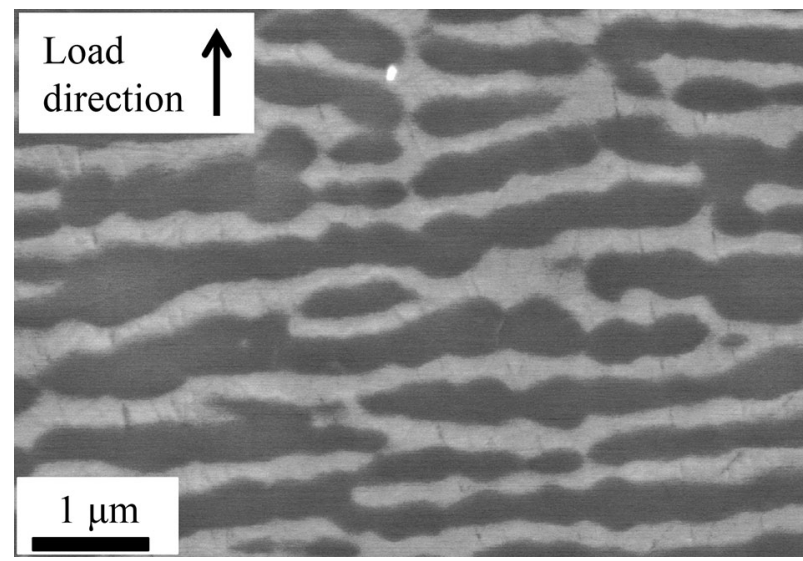

Fig. 7-Backscattered electron image of the $\langle 001\rangle$ specimen subjected to TMF stress relaxation tests at $1223 \mathrm{~K}\left(950{ }^{\circ} \mathrm{C}\right)$ in tension (IP). Rafting of $N$-type.

behavior by the $\langle 011\rangle$ direction has been shown before during tensile testing at $773 \mathrm{~K}\left(500{ }^{\circ} \mathrm{C}\right) .{ }^{[28]}$ In that study, one explanation for the serrated yielding behavior of the $\langle 011\rangle$ direction was the occurrence of dynamic strain aging (DSA) within deformation bands with a high dislocation density. DSA is the interaction between solute atoms and moving dislocations and in areas with
Table II. A Summary of the Observed Deformation Behaviors and Microstructural Features from the TMF Stress Relaxation Tests

\begin{tabular}{|c|c|c|}
\hline & $1023 \mathrm{~K}\left(750{ }^{\circ} \mathrm{C}\right)$ & $1223 \mathrm{~K}\left(950{ }^{\circ} \mathrm{C}\right)$ \\
\hline \multicolumn{3}{|l|}{$\langle 001\rangle$} \\
\hline IP & $\begin{array}{l}\text { vague deformation } \\
\text { bands }\end{array}$ & $\begin{array}{l}\text { very distinct deformation } \\
\text { bands (wavy) } \\
\text { rafting of } N \text {-type } \\
\text { TCP phases }\end{array}$ \\
\hline \multirow[t]{3}{*}{$\mathrm{OP}$} & $\begin{array}{l}\text { vague deformation } \\
\text { bands }\end{array}$ & $\begin{array}{l}\text { very distinct } \\
\text { deformation bands }\end{array}$ \\
\hline & crystallographic & rafting of $P$-type \\
\hline & $\begin{array}{l}\text { deformation inside } \\
\text { the } \gamma^{\prime} \text {-precipitates } \\
\text { (is believed to be } \\
\text { nano-twins) }\end{array}$ & TCP phases \\
\hline \multicolumn{3}{|c|}{ 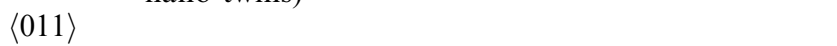 } \\
\hline \multirow[t]{2}{*}{ IP } & $\begin{array}{l}\text { distinct deformation } \\
\text { bands }\end{array}$ & $\begin{array}{l}\text { very distinct } \\
\text { deformation bands }\end{array}$ \\
\hline & serrated yielding & $\begin{array}{l}\text { rafting of } N \text {-type } \\
\text { TCP phases }\end{array}$ \\
\hline \multirow[t]{2}{*}{$\mathrm{OP}$} & $\begin{array}{l}\text { distinct deformation } \\
\text { bands }\end{array}$ & $\begin{array}{l}\text { very distinct } \\
\text { deformation bands }\end{array}$ \\
\hline & serrated yielding & $\begin{array}{l}\text { rafting of } P \text {-type } \\
\text { TCP phases }\end{array}$ \\
\hline \multicolumn{3}{|l|}{$\langle 111\rangle$} \\
\hline IP & vague deformation bands & not tested \\
\hline $\mathrm{OP}$ & vague deformation bands & not tested \\
\hline
\end{tabular}

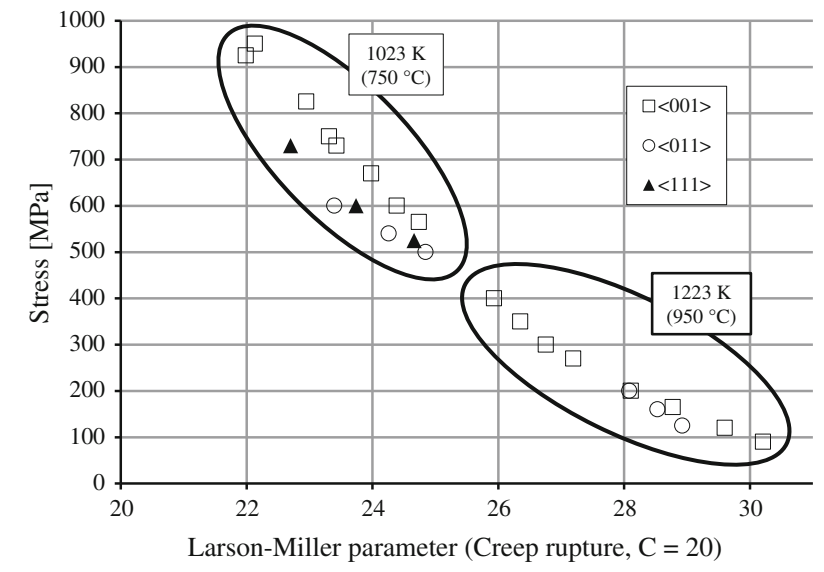

Fig. 8-Larson-Miller plot from the constant load creep tests.

a high dislocation density DSA is more likely to occur. Since it is only the $\langle 011\rangle$ direction that shows distinct deformation bands at this temperature, it is thus likely that DSA has occurred during loading into the TMF cycle. Other studies have also reported a serrated yielding behavior for the $\langle 011\rangle$ direction, see for instance. ${ }^{[29-32]}$ One explanation for this has been that only one slip system is active during deformation of the $\langle 011\rangle$ direction while multiple slip systems are active during plastic deformation in the $\langle 001\rangle$ direction. ${ }^{[29]}$ The fact that all specimens subjected to stress relaxation at $1223 \mathrm{~K}\left(950{ }^{\circ} \mathrm{C}\right)$ show distinct deformation bands on the surfaces but no serrated yielding, still has to be investigated. 


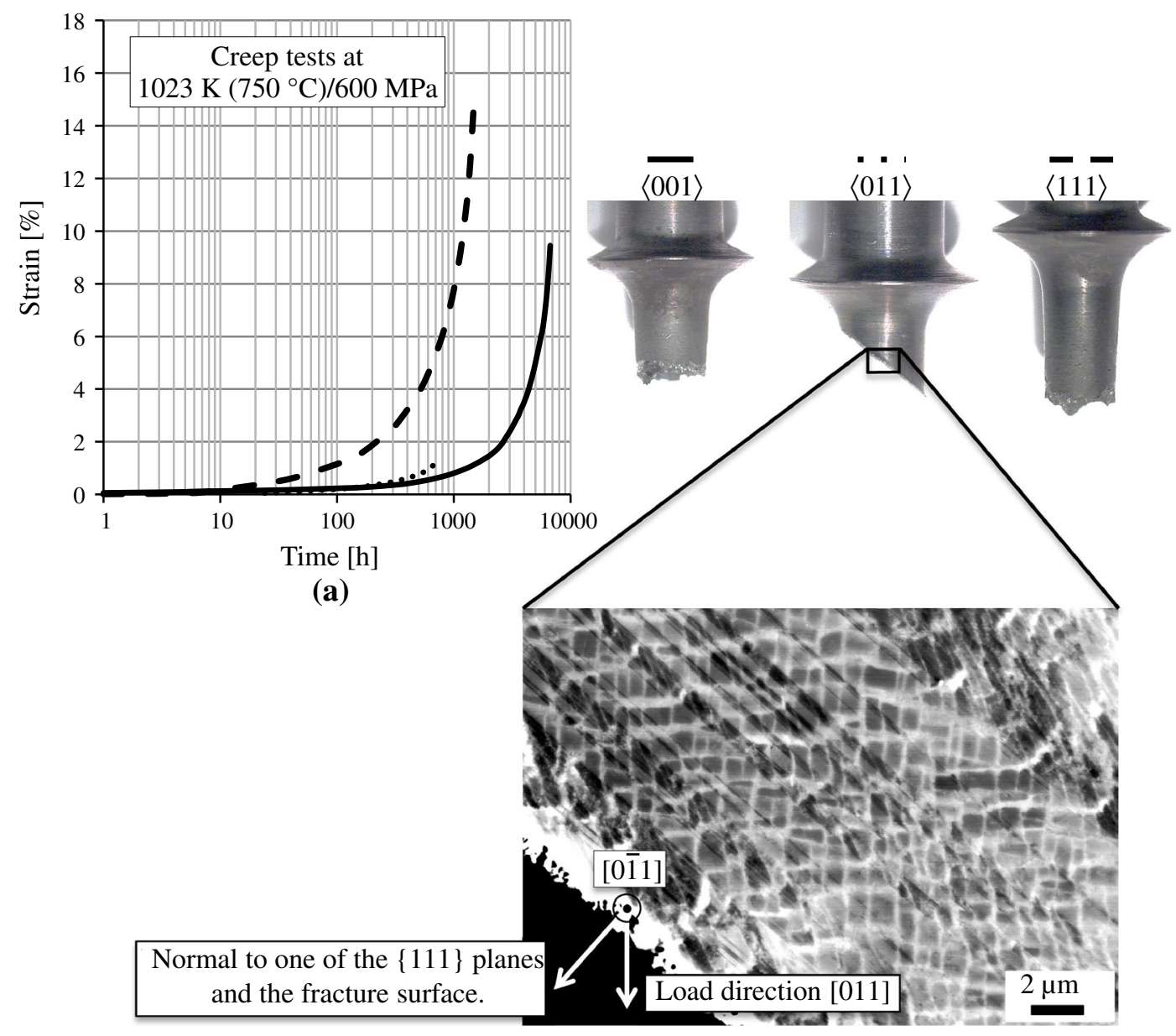

(b)

Fig. 9- (a) Creep curves at $1023 \mathrm{~K}\left(750^{\circ} \mathrm{C}\right)$ and $600 \mathrm{MPa}$ for the $\langle 001\rangle,\langle 011\rangle$, and $\langle 111\rangle$ orientations. The creep specimens have a diameter of $5 \mathrm{~mm}$. (b) A backscattered electron image showing an area close to the fracture surface for the $\langle 011\rangle$ direction.

During loading into the TMF cycle for the stress relaxation tests at $1023 \mathrm{~K}\left(750{ }^{\circ} \mathrm{C}\right)$ a clear noise was heard from specimens loaded in the $\langle 011\rangle$ direction. This behavior of the $\langle 011\rangle$ direction has been reported before when acoustic emission (AE) was used to measure noise during plastic deformation. ${ }^{[33]}$ In that study, loading in the $\langle 011\rangle$ direction led to higher AE signals and higher noise compared to the $\langle 001\rangle$ direction. It is thus likely, that during loading of the $\langle 011\rangle$ direction at this temperature, in which serrated yielding occurs, a high noise is created for each serration.

During TMF stress relaxation both the $\langle 001\rangle$ and $\langle 011\rangle$ directions show precipitation of TCP phases and this will probably influence the behavior of the material. The TCP phases will drain the $\gamma$-matrix of some of the most important strengthening elements and thus decreases the material's resistance to creep deformation. A previous study has shown how the TCP phases precipitate inside shear bands on the expense of the $\gamma$-matrix when pre-strained CMSX-4 material is exposed to $1223 \mathrm{~K}\left(950{ }^{\circ} \mathrm{C}\right)$ for more than 10 hours. ${ }^{[34]}$ Another study has also shown that TCP phases play a dominant role for the observed variability in creep life during high temperature creep. ${ }^{[35]}$ However, this scatter is mainly associated with a highly localized failure process around the TCP phases during tertiary creep while the creep rates during primary and secondary creep are very reproducible. However, since TCP phase formation was observed for all directions in this study it seems that it does not affect the material anisotropy.

\section{B. Tension/Compression Asymmetry}

A tension/compression asymmetry is observed for all crystal orientations during the TMF stress relaxation tests, see Figure 2 . At $1023 \mathrm{~K}\left(750^{\circ} \mathrm{C}\right)$, a greater asymmetry is observed for the $\langle 001\rangle$ direction compared to both the $\langle 011\rangle$ and $\langle 111\rangle$ directions. At this temperature the $\langle 001\rangle$ and $\langle 111\rangle$ specimens are stronger in tension than compression. However, for the $\langle 011\rangle$ specimens the opposite behavior is observed; compressive loading leads to a higher stress state compared to tensile loading. On the other hand at $1223 \mathrm{~K}\left(950{ }^{\circ} \mathrm{C}\right)$, an opposite tension/compression asymmetry is observed: the $\langle 001\rangle$ direction is stronger in compression than tension and the $\langle 011\rangle$ direction is stronger in 


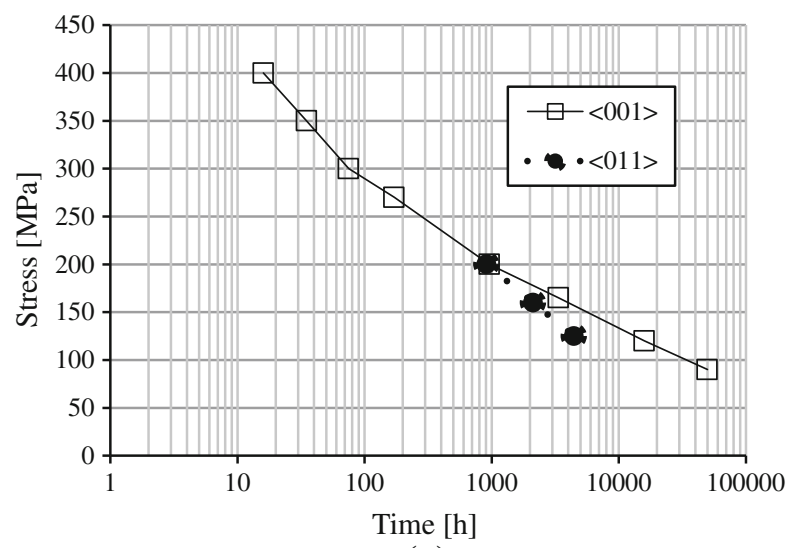

(a)

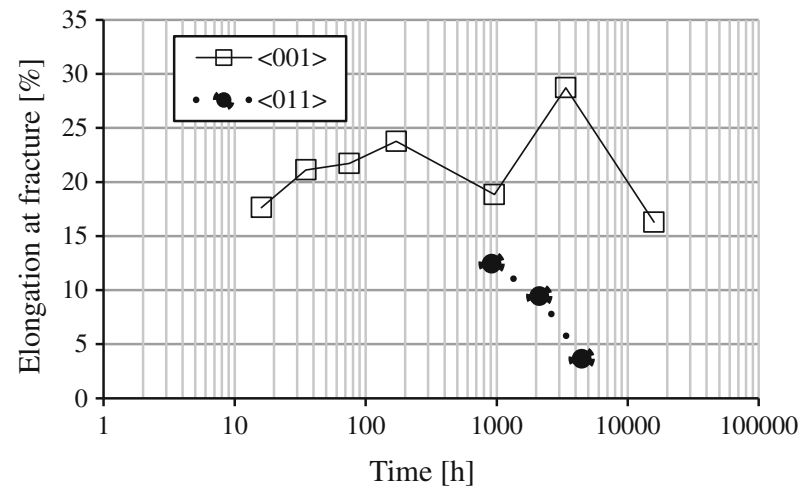

(b)

Fig. 10 - Creep tests at $1223 \mathrm{~K}\left(950{ }^{\circ} \mathrm{C}\right),(a)$ stress $v s$ time and $(b)$ elongation at fracture $v s$ time.

Table III. Elastic Constants at Both $1023 \mathrm{~K}\left(750^{\circ} \mathrm{C}\right)$ and $1223 \mathrm{~K}\left(950{ }^{\circ} \mathrm{C}\right)$ for All Tested Crystal Orientations

\begin{tabular}{lcl}
\hline & $1023 \mathrm{~K}\left(750{ }^{\circ} \mathrm{C}\right)$ & $1223 \mathrm{~K}\left(950{ }^{\circ} \mathrm{C}\right)$ \\
\hline$E_{\langle 001\rangle}(\mathrm{GPa})$ & 95 & 80 \\
$E_{\langle 011\rangle}(\mathrm{GPa})$ & 170 & 158 \\
$E_{\langle 111\rangle}(\mathrm{GPa})$ & 245 & not tested \\
\hline
\end{tabular}

tension than compression. It seems that there is a change in tension/compression asymmetry during TMF stress relaxation when going from $1023 \mathrm{~K}$ to $1223 \mathrm{~K}\left(750{ }^{\circ} \mathrm{C}\right.$ to $\left.950{ }^{\circ} \mathrm{C}\right)$. Ezz et al. ${ }^{[6]}$ have showed that the tension/ compression asymmetry changes with temperature as they showed that the critical resolved shear stress (CRSS) is higher in tension than compression at around $1023 \mathrm{~K}\left(750^{\circ} \mathrm{C}\right)$ for orientations close to [001] in the stereographic triangle. On the other hand, for materials close to [011] and [111] in the stereographic triangle there was a smaller asymmetry in CRSS at this temperature. At higher temperatures the asymmetry decreased. The present study shows that there is a change in tension/compression asymmetry also in TMF stress relaxation. However, the reason for this change is still to be found. One reason for why the $\langle 001\rangle$ direction is stronger in tension than compression during TMF stress relaxation at $1023 \mathrm{~K}\left(750{ }^{\circ} \mathrm{C}\right)$ may be attributed to the type of deformation created during compression shown in Figure 6. This type of deformation is believed to be nano-twinning, but without TEM or EBSD this cannot be proven. However, previous research by Tsuno et al. ${ }^{[4]}$ shows that twinning may occur during compression creep and thereby weaken the material. In that study the creep asymmetry also increased with increased temperature, however from the TMF stress relaxation tests in this study it seems that the tension/compression asymmetry is slightly smaller at $1223 \mathrm{~K}\left(950^{\circ} \mathrm{C}\right)$ compared to $1023 \mathrm{~K}\left(750{ }^{\circ} \mathrm{C}\right)$.

Rafting of the $\gamma / \gamma^{\prime}$-microstructure is observed from TMF stress relaxation at $1223 \mathrm{~K}\left(950^{\circ} \mathrm{C}\right)$, however it seems that $1023 \mathrm{~K}\left(750^{\circ} \mathrm{C}\right)$ is a too low temperature for rafting to occur in this type of test. For the $\langle 001\rangle$ direction in compression, rafts parallel ( $P$-type) to the loading direction are obtained, while in tension, rafts transverse ( $N$-type) to the loading direction are created. Previous research has shown that pre-rafts parallel to the loading direction can enhance TMF properties ${ }^{[36]}$ as well as the non-isothermal creep properties. ${ }^{21]}$ Another study has shown that rafts parallel to the loading direction may slow down the process of dislocation climb and therefore improve high temperature creep properties. ${ }^{[18]}$ At $1223 \mathrm{~K}\left(950{ }^{\circ} \mathrm{C}\right)$, the $\langle 001\rangle$ direction is stronger in compression than tension, however the opposite relationship is observed at $1023 \mathrm{~K}\left(750^{\circ} \mathrm{C}\right)$, where no rafting is visible. The creation of rafts parallel to the loading direction in compression at $1223 \mathrm{~K}$ $\left(950{ }^{\circ} \mathrm{C}\right)$ might therefore be one reason for why the $\langle 001\rangle$ direction is stronger in compression than tension at this temperature.

It has been shown that dendritic stresses from solidification will influence the degree of rafting. ${ }^{[37,38]}$ One may also argue that those dendritic stresses can influence the tension/compression asymmetry (as well as the anisotropy). ${ }^{[39,40]}$ But since the material in this study is plastically deformed to obtain approximately $0.5 \mathrm{pct}$ inelastic strain when loading into the TMF cycle, the influence from dendritic stresses is believed to be rather small during long term stress relaxation.

A tension/compression asymmetry was also observed when evaluating the creep rates from the TMF stress relaxation tests. The highest degree of tension/compression asymmetry is detected for the $\langle 001\rangle$ direction at $1023 \mathrm{~K}\left(750^{\circ} \mathrm{C}\right)$, see Figure 11(a). Here the creep rate in compression is ten times greater compared to the tensile creep rate. Regarding the $\langle 011\rangle$ and $\langle 111\rangle$ directions at this temperature no significant tension/compression asymmetry can be observed. At $1223 \mathrm{~K}\left(950{ }^{\circ} \mathrm{C}\right)$ both the $\langle 001\rangle$ and $\langle 011\rangle$ directions show a small tension/ compression asymmetry in creep rate.

\section{Comparison Between TMF Stress Relaxation Creep Rates and Constant Load Creep Rates}

Figures 11(a) through (c) provide a comparison in creep rates for the TMF stress relaxation and constant load creep tests for all crystal orientations and temperatures addressed in this study. In general, a good agreement is observed between the creep from the two 


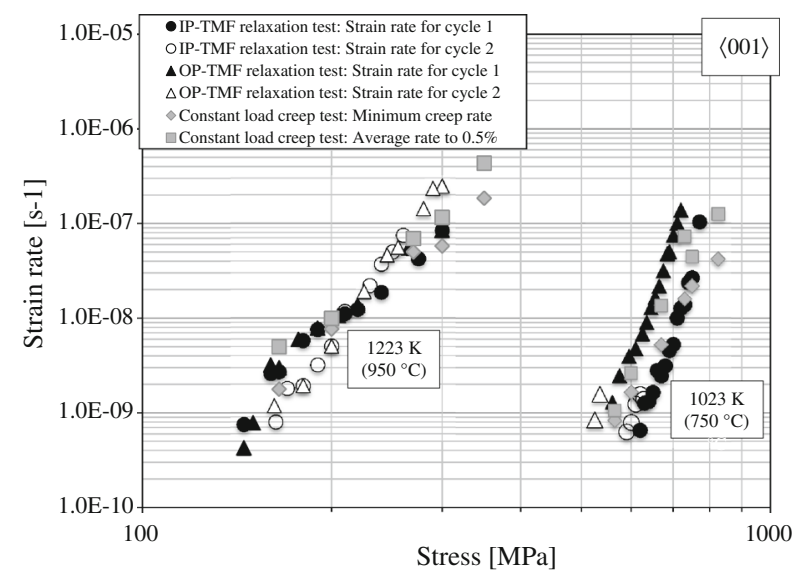

(a)

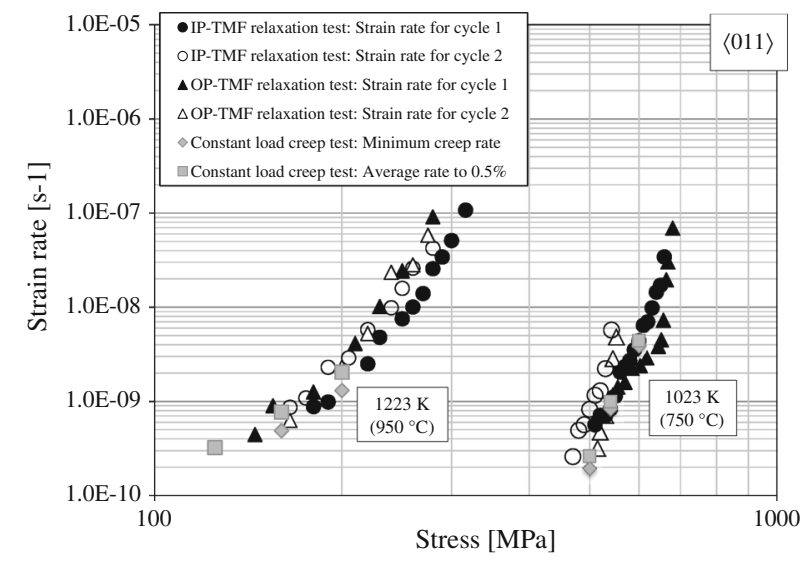

(b)

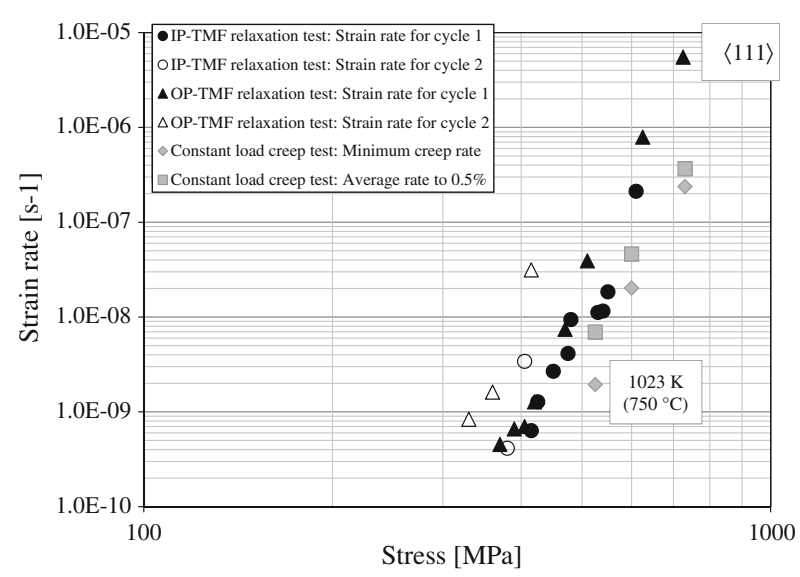

(c)

Fig. $11-$ Creep rates from the TMF stress relaxation tests and the conventional constant load creep tests in the $(a)\langle 001\rangle$ direction, $(b)\langle 011\rangle$ direction, (c) $\langle 111\rangle$ direction.

types of testing. This is very beneficial since the TMF stress relaxation testing is much more time efficient compared to conventional creep testing. However, this does not imply that all creep testing can be replaced by stress relaxation testing. But, for example when performing material modeling of TMF behavior in critical gas turbine components creep rates are needed, and if these creep rates can be obtained from the more time efficient stress relaxation tests it is thus very favorable.

\section{The Influence of TMF Cycling on Creep Rates}

It is of interest to study how TMF cycling influences the creep rates of single-crystal superalloys. The stress relaxation tests in this study were performed as two TMF cycles with a 100 hours dwell time during each cycle. Generally an increase in creep rate is observed for all crystal orientations in the second TMF cycle compared to the first TMF cycle, see Figures 12(a) through (d). However, after some time the creep rates decrease and finally agrees with the creep rate shown in the first cycle. Consider a specimen that is subjected to a tensile TMF cycle, which at loading will introduce plastic deformation in the material and during the dwell time, the material will undergo creep relaxation (please see Reference 41 for detailed plots of hysteresis loops during TMF). After the first 100 hours TMF cycle the specimen is unloaded to zero strain and $373 \mathrm{~K}\left(100{ }^{\circ} \mathrm{C}\right)$, which means that the material will go in compression and deform plastically. During this plastic deformation at low temperature, dislocations will form in the microstructure. When loading into the second TMF cycle, the amount of plastic deformation introduced in the material will lead to a momentarily increase in creep rate before the material starts to relax at a high temperature and the creep rate adapts to the creep rate shown during the first TMF cycle. In this study only two TMF cycles were applied before the tests were stopped. Applying additional TMF cycles with long dwell times will probably affect the creep rates even more but this is still to be investigated.

\section{CONCLUSIONS}

The aim of this study was to investigate the stress relaxation behavior during component like TMF cycling 


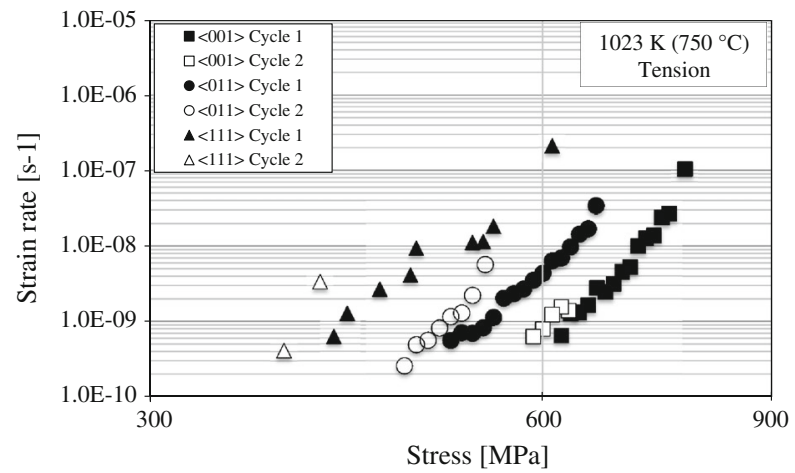

(a)

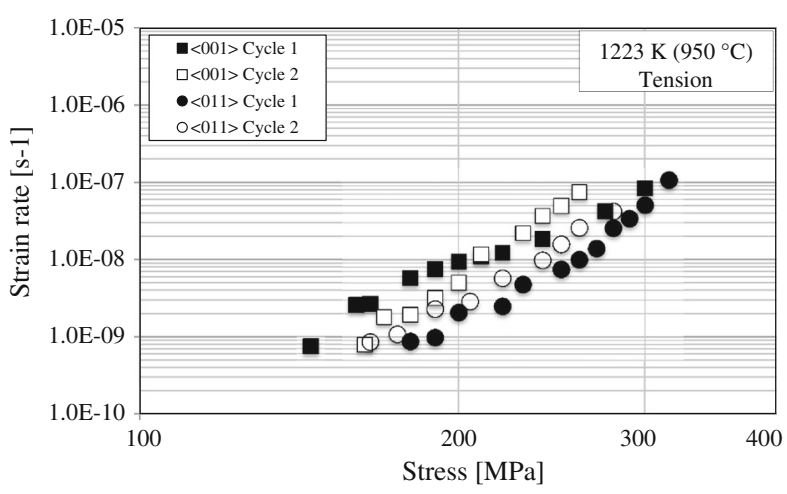

(c)

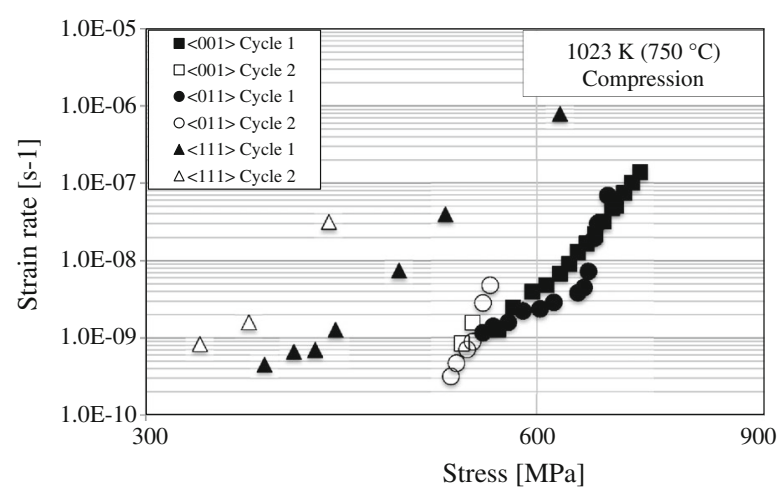

(b)

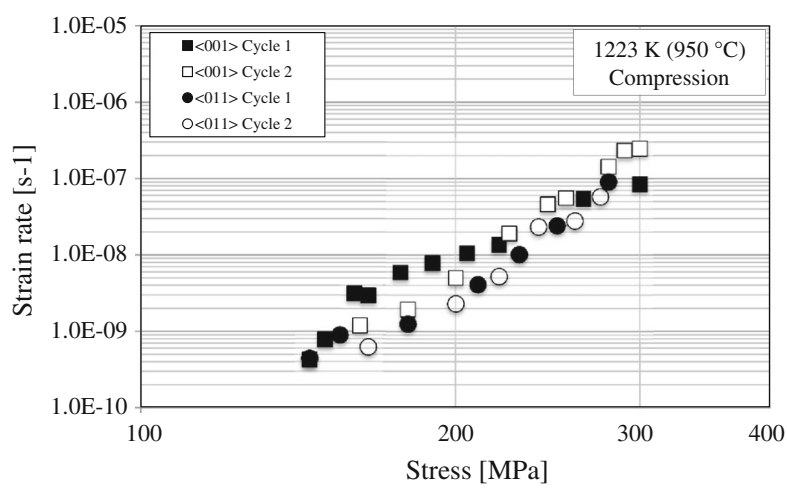

(d)

Fig. $12-(a)$ Tensile creep rates at $1023 \mathrm{~K}\left(750{ }^{\circ} \mathrm{C}\right)$ from the TMF stress relaxation tests. $(b)$ Compressive creep rates at $1023 \mathrm{~K}\left(750{ }^{\circ} \mathrm{C}\right)$ from the TMF stress relaxation tests. (c) Tensile creep rates at $1223 \mathrm{~K}\left(950^{\circ} \mathrm{C}\right)$ from the TMF stress relaxation tests. $(d)$ Compressive creep rates at $1223 \mathrm{~K}\left(950^{\circ} \mathrm{C}\right)$ from the TMF stress relaxation tests.

for a Ni-based single-crystal superalloy in different directions, in both tension and compression and at different temperatures. Following conclusions can be drawn from this study:

1. The TMF stress relaxation behavior is highly anisotropic. At $1023 \mathrm{~K}\left(750{ }^{\circ} \mathrm{C}\right)$ the $\langle 001\rangle$ direction shows slightly better properties compared to the $\langle 011\rangle$ direction while the $\langle 111\rangle$ direction seems to have the worst properties during TMF stress relaxation.

2. A tension/compression asymmetry during TMF stress relaxation is observed for all directions. The highest degree of asymmetry is observed for the $\langle 001\rangle$ direction at $1023 \mathrm{~K}\left(750{ }^{\circ} \mathrm{C}\right)$ where the creep rate is in the order of ten times higher in compression than tension. Generally, a greater tension/compression asymmetry is observed at $1023 \mathrm{~K}\left(750{ }^{\circ} \mathrm{C}\right)$ compared to $1223 \mathrm{~K}\left(950{ }^{\circ} \mathrm{C}\right)$ during $\mathrm{TMF}$ stress relaxation.

3. From the conventional constant load creep tests, the $\langle 011\rangle$ direction shows poor creep ductility and crystallographic fractures along one of the $\{111\}$ planes. As a consequence, the time to rupture in the constant load creep tests is low for this orientation even if the creep rates in the TMF stress relaxation tests in most cases are better or comparable to the other directions.

4. When comparing creep rates from the TMF stress relaxation tests with creep rates from the constant load creep tests a good agreement is found. Obtaining creep rates from the more time efficient TMF stress relaxation tests might be beneficial when performing material modeling of TMF behavior of critical gas turbine components. Finally it is to be noted that TMF cycling seems to influence the creep rates temporarily.

\section{ACKNOWLEDGMENTS}

The work has been financially supported by Siemens Industrial Turbomachinery $\mathrm{AB}$ in Finspång, Sweden and the Swedish Energy Agency, via the Research Consortium of Materials Technology for Thermal Energy Processes, Grant No. KME-502. In addition, the support from the Swedish Government Strategic Research Area in Materials Science on Functional Materials at Linköping University (Faculty Grant SFOMat-LiU \# 2009-00971) is also acknowledged.

\section{REFERENCES}

1. R.C. Reed, T. Tao, and N. Warnken: Acta Mater., 2009, vol. 57, pp. 5898-913.

2. T.M. Pollock and S. Tin: J. Propuls. Power, 2006, vol. 22, pp. 36174. 
3. R.C. Reed: The Superalloys-Fundamentals and Applications, Cambridge University Press, Cambridge, 2006.

4. N. Tsuno, S. Shimabayashi, K. Kakehi, C.M.F. Rae, and R.C. Reed: Superalloys 2008, R.C. Reed, K.A. Green, P. Caron, T.P. Gabb, M.G. Fahrman, E.S. Huron, and S.A. Woodard, eds., TMS, Warrendale, PA, 2008, pp. 433-42.

5. R.V. Miner, T.P. Gabb, and J. Gayda: Metall. Trans. A, 1986, vol. 17, pp. $507-12$.

6. S.S. Ezz, D.P. Pope, and V. Paidar: Acta Metall., 1982, vol. 30, pp. 921-26.

7. D. Leidermark, J.J. Moverare, S. Johansson, K. Simonsson, and S. Sjöström: Acta Mater., 2010, vol. 58, pp. 4986-97.

8. M. Segersäll, J.J. Moverare, K. Simonsson, and S. Johansson: Superalloys 2012, E.S. Huron, R.C. Reed, M.C. Hardy, M.J. Mills, R.E. Montero, P.D. Portella, and J. Telesman, eds., TMS, Warrendale, PA, 2012, pp. 215-23.

9. J.J. Moverare, S. Johansson, and R.C. Reed: Acta Mater., 2009, vol. 57, pp. 2266-76.

10. Y. Ro, H. Zhou, Y. Koizumi, T. Yokokawa, T. Kobayashi, H. Harada, and I. Okada: Mater. Trans., 2004, vol. 45, pp. 396-98.

11. J.X. Zhang, H. Harada, Y. Ro, Y. Koizumi, and T. Kobayashi: Acta Mater., 2008, vol. 56, pp. 2975-87.

12. M. Dupeux, J. Henriet, and M. Ignat: Acta Metall., 1987, vol. 35, pp. 2203-12.

13. U. Martin, U. Mühle, and H. Oettel: Mech. Time Depend. Mater., 1998, vol. 2, pp. 1-12.

14. H. Mughrabi: Mater. Sci. Technol., 2009, vol. 25, pp. 191-204.

15. N. Matan, D.C. Cox, C.M.F. Rae, and R.C. Reed: Acta Mater., 1999, vol. 47, pp. 2031-45.

16. R.C. Reed, N. Matan, D.C. Cox, M.A. Rist, and C.M.F. Rae: Acta Mater., 1999, vol. 47, pp. 3367-81.

17. T.M. Pollock and A.S. Argon: Acta Metall. Mater., 1994, vol. 42, pp. 1859-74.

18. U. Tetzlaff and H. Mughrabi: Superalloys 2000, T.M. Pollock, R.D. Kissinger, R.R. Bowman, K.A. Green, M. McLean, S. Olson, and J.J Schirra, eds., TMS, Warrendale, PA, 2000, pp. 273 82.

19. H. Mughrabi and U. Tetzlaff: Adv. Eng. Mater., 2000, vol. 2, pp. 319-26.

20. M. Ott and H. Mughrabi: Mater. Sci. Eng. A, 1999, vol. 272, pp. $24-30$

21. R. Giraud, J. Cormier, Z. Hervier, D. Bertheau, K. Harris, J. Wahl, X. Milhet, J. Mendez, and A. Organista: Superalloys 2012,
E.S. Huron, R.C. Reed, M.C. Hardy, M.J. Mills, R.E. Montero, P.D. Portella, and J. Telesman, eds., TMS, Warrendale, PA, 2012, pp. 265-74.

22. D. Chatterjee, N. Hazari, N. Das, and R. Mitra: Mater. Sci. Eng. $A$, 2010, vol. 528, pp. 604-13.

23. P. Lukáš, J. Cadek, V. Sustek, and L. Kunz: Mater. Sci. Eng. A, 1996, vol. 208, pp. 149-57.

24. K. Kakehi: Scripta Mater., 1999, vol. 41, pp. 461-65.

25. K. Kakehi: Mater. Sci. Eng. A, 2000, vol. 278, pp. 135-41.

26. E.W. Hart: J. Eng. Mater. Technol., 1976, vol. 98, pp. 193-202.

27. D.A. Woodford: Mater. Des., 1993, vol. 14, pp. 231-42.

28. M. Segersäll and J.J. Moverare: Materials, 2013, vol. 6, pp. 43744.

29. R.V. Miner, R.C. Voigt, J. Gayda, and T.P. Gabb: Metall. Trans. A, 1986, vol. 17A, pp. 491-96.

30. T.S. Rong: Intermetallics, 2003, vol. 11, pp. 151-55.

31. X. Wu, J.H. Zhang, J.L. Liu, T. Jin, Y.B. Xu, and Z.Q. Hu: Mater. Sci. Eng. A, 2002, vol. 325, pp. 478-83.

32. E.F. Westbrooke, L.E. Forero, and F. Ebrahimi: Acta Mater., 2005, vol. 53, pp. 2137-47.

33. X.-H. Li and J. Moverare: Proceedings of ASME Turbo Expo, Vienna, Austria, 2004, pp. 1-9.

34. B.G. Choi, C.Y. Jo, H.U. Hong, I.S. Kim, S.M. Seo, and H.M. Kim: Trans. Nonferr. Met. Soc. China, 2011, vol. 21, pp. 1291-96.

35. J.-B. Le Graverend, J. Cormier, S. Kruch, F. Gallerneau, and J. Mendez: Metall. Mater. Trans. A, 2012, vol. 43A, pp. 3988-97.

36. F.C. Neuner, U. Tetzlaff, and H. Mughrabi: Thermomechanical Fatigue Behaviour of Materials, 4th ed., ASTM International, West Conshohocken, PA, 2002, pp. 112-26.

37. A. Epishin, T. Link, U. Brückner, and B. Fedelich: Phys. Met. Metallogr., 2004, vol. 100, pp. 192-99.

38. B. Fedelich, A. Epishin, T. Link, H. Klingelhöffer, G. Künecke, and P.D. Portella: Superalloys 2012, E.S. Huron, R.C. Reed, M.C. Hardy, M.J. Mills, R.E. Montero, P.D. Portella, and J. Telesman, eds., TMS, Warrendale, PA, 2012, pp. 491-500.

39. K.Y. Cheng, C.Y. Jo, D.H. Kim, T. Jin, and Z.Q. Hu: Mater. Charact., 2009, vol. 60, pp. 210-18.

40. R.C. Reed, D.C. Cox, and C.M.F. Rae: Mater. Sci. Technol., 2007, vol. 23, pp. 893-902.

41. J.J. Moverare, M. Segersäll, A. Sato, S. Johansson, and R.C. Reed: Superalloys 2012, E.S. Huron, R.C. Reed, M.C. Hardy, M.J. Mills, R.E. Montero, P.D. Portella, and J. Telesman, eds., TMS, Warrendale, PA, 2012, pp. 369-77. 